\title{
PARIS AND SPAIN IN ERNEST HEMINGWAY'S NOVEL THE SUN ALSO RISES
}

Ivana Čuljak, University of Mostar, skegro.ivana@gmail.com

10.31902/fll.24.2018.7

UDK 821.111(73).09-31

\begin{abstract}
Ernest Hemingway was born in Oak Park, Illinois yet he wrote more about other places than about his birthplace. His first novel The Sun Also Rises has Paris and Spain for the setting. It starts in Paris, culminates in Spain, and ends with Jake and Brett leaving Spain. In Hemingway's novel, a group of friends wanders from place to place with no fixed destination showing that they are the lost generation with no aim in their lives. This paper will show how this group of friends is affected by their destinations with modern, cool Paris that mutes and controls their passions and Spain's fiesta where they go berserk. In Hemingway's novel, Paris and Spain are the two ends of the spectrum. In Paris one can see everything - from homosexuals to prostitutes, and Spain is more traditional and looks down on Brett because of her hairstyle and her wardrobe. One perceives Paris and Spain as romantic places, yet Hemingway shows that Paris is the place of twisted sexuality while Spain is more conservative.
\end{abstract}

Keywords: Paris, Spain, destination, lost generation, bullfight, fiesta.

Hemingway was born and raised in Oak Park, Illinois, but he was more attracted to other places such as Paris or Spain. Paris of his time was popular among Americans and many expatriates lived there. Hemingway spent six years in Paris in the 1920s. It was this city that made him famous and in six years there he crafted his style. In this city he met his tutors Gertrude Stein and Ezra Pound who instructed him on writing; he made friends with Sylvia Beach whose Shakespeare and Company bookstore and lending library made possible for him to read modern fiction; in Paris he met the Irish exile James Joyce; he became friends with the Fitzgeralds, and Francis Scott Fitzgerald helped him a lot with his advice and by introducing him to other influential people. During the 1920s, the decade that the French call Les annees folles ("the crazy years") (Kennedy 198), Paris was the capital of high modernism. Picasso and Duchamp, Stravinsky, Poulenc, and Satie, Breton, Proust, Stein, and Joyce experimented in modern art, music, and literature (Kennedy 198). Those who lived there during those years were extremely lucky. As Hemingway later acknowledged in $A$ Moveable Feast: "To have come on all this new world of writing, with 
time to read in a city like Paris where there was a way of living well and working, no matter how poor you were, was like having a great treasure given to you" (qtd. in Kennedy 198).

Those early years in Paris he spent with his first wife Hadley and his son "Bumby." Hemingway had married Hadley in September 1921 and three months later they sailed to Paris on the advice of his mentor Sherwood Anderson who gave him the letters of introduction for Stein, Pound, and Beach (Kennedy 198). Anderson convinced him that the Left Bank is the place to launch his career. According to the author's posthumously published memoir, he and Hadley had "the lovely magic time" (qtd. in Kennedy 199) mostly in Europe until Hemingway fell in love with Hadley's friend Pauline Pfeiffer. During those years he published two chapbooks (Three Stories and Ten Poems and in our time), a story sequence, In Our Time, and his first novel, The Sun Also Rises. The couple took an apartment on the rue Notre-Damedes-Champs. During that year he completed three of his finest short stories: Indian Camp, Soldier's Home, and Big Two-Hearted River (Kennedy 199).

Life in Paris changed Hemingway; he wanted to succeed so badly as a writer and felt trapped in a marriage to an older woman. Paris was exciting and he "relished the attention of chic, sexually adventurous women" (Kennedy 199). When he met Duff Twysden who was the model for his Brett Ashley, Hemingway was smitten and Hadley was desperate since he openly flirted with Duff (Barlowe 28). Duff was modern, sexually adventurous woman that attracted Hemingway and that type of woman was more likely to be found in Paris than in other places.

Paris of Hemingway's time was progressive and had over eighty feminist societies representing more than sixty thousand members (Martin 68). Many of the women Hemingway encountered in Paris embraced sexual freedom, including Gertrude Stein, the legendary lesbian hostess of the most stimulating salon for writers and artists in Paris. Paris offered freedom and no one was judgmental there: Jake takes a prostitute for a dinner and brings her among his friends, Brett hangs out with homosexuals, Mike is a bankrupt and a drunk but no one holds it against him. In Paris, people are accepted as they are. Hemingway's sentences make us visualize beautiful Parisian streets with their lights, people dancing in the bars, and Parisian night world. Sexuality is not taken seriously but as something fun with no boundaries. However, Jake is irritated by the group of homosexuals that arrive with Brett, which shows that Jake is not perfectly okay with this urban setting and sexual freedoms that Paris offers. 
Paris of Hemingway's time is the place of blurred gender relations. Hemingway mentions a controversial dance hall frequented by homosexuals and lesbians. Hemingway's characters visit the dance hall in the Pantheon Quarter, and it is there that Jake unexpectedly meets Brett. From the moment when Jake meets Brett, the atmosphere is getting more and more charged until it culminates in Spain. The impotent Jake escorts a prostitute, while the oversexed Brett arrives with a group of homosexuals. When the two decide to leave together, taking a taxi to the Pare Montsouris, they follow a route that Hemingway knew very well. They pass through "a dark street behind St. Etienne du Mont," the rue Descartes, where the author had rented a writing studio for a short time in early 1922 (Kennedy 203). The taxi then passes the Place Contrescarpe, the hub of the neighbourhood in which the Hemingways first lived and a place described in the opening paragraph of $A$ Moveable Feast (Kennedy 203). Jake and Brett continue onto "the cobbles of the rue Mouffetard," depicted in the memoir as "that wonderful narrow crowded market street which led into the Place Contrescarpe" ( $A$ Moveable Feast 3 qtd. in Kennedy 203). Those streets reveal the inner conflict inside Hemingway-they remind him of the happy time with Hadley but they also reveal his inner desire to "gaze the erotic play from which he has been cruelly excluded" (Kennedy 203) because of his marriage to Hadley. Life in Paris is exciting and sexually charged, yet Hemingway, just like Jake, cannot fully enjoy it.

Paris at that time was progressive and Hemingway witnessed the appearance of the New Woman-a woman who was no longer the housebound nurturer but an educated woman who valued her autonomy and did not automatically subscribe to the values of the family; frequently, she was single and had a career. This New Woman is a challenge to the traditional social structure, and she can be seen in the character of Lady Brett Ashley "who has stepped off the pedestal and now roams the world" (Martin 68). Brett is dressed fashionably, has short hair, and uses wardrobe to emphasize her sexuality.

Jake and Brett's relationship is peculiar; they embody new gender relations. Jake is the one who is impotent and who cries when alone in his bedroom and Brett is the one who excessively drinks, swears, and changes sexual partners. The 1920s are the period of gender reversal and sexual confusion and this can be seen in their relationship. While Brett and other characters sometimes behave irresponsibly, Jake is the reasonable one in the group. He tolerates other people's foolishness; he pays the prostitute even though he does not sleep with her; he accepts Brett's sexuality the way it is and he 
comes to her rescue at the end of the novel even though she does not deserve it. Brett resembles a traditional man in her sexual expectations and Jake resembles a traditional woman in his sexual unavailability and his uncomplaining tolerance of other people's reckless behaviour. Different gender roles between them mirror sexual confusion in the society at large. Traditional moral standards have disappeared and the emphasis is not on love anymore but on casual meaningless sexual arrangements.

Although it seems that Paris was a perfect place to live in since it was modern, artistic, and liberal, Hemingway saw its bad sides as well. His ambivalent attitude toward Paris can be seen almost at the beginning of the novel in one of the descriptions of Paris:

It was a warm spring night and I sat at a table on the terrace of the Napolitain after Robert had gone, watching it get dark and the electric signs come on, and the red and green stopand-go traffic-signal, and the crowd going by, and the horsecabs clippety-clopping along at the edge of the solid taxi traffic, and the poules going by, singly and in pairs, looking for the evening meal. (The Sun Also Rises 149-152)

The first part of the sentence describes a night in Paris and the pictures one visualizes are pleasant: the night is warm, it is spring, he enjoys the night, there are electric lights slowly turning on. However, the second part of the sentence is completely different: poules (which is French for young promiscuous women) are passing by the café. This sentence perfectly explains Hemingway's feelings about Paris. Paris is a modern and liberal city, but there is the other side of modernism and liberalism: sexuality went wrong. Prostitutes are on the street near the café and it is seen as a normal thing.

In this part of the novel, there are other instances of Hemingway's ambivalent attitude. Jake is surprised to hear that Georgette (the prostitute) does not like Paris and through her words one can see the other Paris: dirty and sick. She says:

"What's the matter? You sick?"

"Yes."

“Everybody's sick. I'm sick, too." (SAR 172-173)

Her words imply sexual corruption and the spread of sexual diseases which is the counter effect of progressive and modern ideas of Paris. However, her words also have another meaning: every 
character in the novel is sick. They either have a real illness (just like Jake who was wounded in the war) or they suffer from other "diseases"-moral (Brett), financial (Mike), or emotional (Cohn and Jake). Brett suffers from a moral "disease"; she is promiscuous and does not care about other people's feelings. Mike suffers from a financial "disease"; he is a bankrupt and a drunk whose debts are piling up. Cohn and Jake suffer from an emotional "disease": they are in love with Brett but their love is not returned. This general sense of malaise is symptomatic of a post-war condition. When Jake brings Georgette among his friends, Jake's acquaintance Frances Clyne and Georgette talk about Paris:

"Have you been in Paris long? Do you like it here? You love Paris, do you not?"

"No, I don't like Paris. It's expensive and dirty."

"Really? I find it so extraordinarily clean. One of the cleanest cities in all Europe."

"I find it dirty."

"How strange! But perhaps you have not been here very long." "I've been here long enough."

"But it does have nice people in it. One must grant that." Georgette turned to me. "You have nice friends." (SAR 223-228)

This conversation between Frances and Georgette shows two contradicting opinions on Paris. Georgette has the sense that something is wrong with this urban space. Since she gets in contact with people of Paris who are mostly sick and twisted, she sees Paris as dirty and sick, but Frances who is upper-class does not understand that there is another side of Paris. When Georgette says that Paris is dirty Frances takes it literally and says that Paris is the cleanest city in all Europe and that the people are nice.

Robert Cohn does not like Paris either. Cohn wants to go to South America because he feels that he does not live his life to the fullest: '“Listen, Jake,' he leaned forward on the bar. 'Don't you ever get the feeling that all your life is going by and you're not taking advantage of it? Do you realize you've lived nearly half the time you have to live already?"' (SAR 117-118). His words can apply to every character in the novel-they are watching the life goes by and they do nothing about it. His attitude is typical of the lost generation who witnessed the war and cannot go back to living the normal life. Jake reveals that he has got certain problems as well and gives Cohn an 
advice: "'Listen, Robert, going to another country doesn't make any difference. I've tried all that. You can't get away from yourself by moving from one place to another. There's nothing to that.'" (SAR 124-125) His sentence is the motto of the novel: no matter where you live, your problems will not disappear. He further advises Cohn: "This is a good town. Why don't you start living your life in Paris?"' (SAR 127) and his words are ironic since all of them are stuck and cannot go on with their lives. Cohn considers Paris boring which is absurd since Paris at that time was the centre of art, modernism, and urban night life. He has inner restlessness which cannot be cured by anything.

Jake and his friends live a comfortable life in Paris; they party and drink, and it seems that Jake is carefree, however, the Paris section which comprises one-third of the novel reveals his impotence which limits his relation to Brett and "haunts his tortured psyche" (Kennedy 202). Nobody knows about this except Brett. Jake admitted to Cohn that he had problems as well, but he did not reveal the problem itself. Jake is torn-he wants Brett and she wants him, yet their relationship is impossible. Although he is impotent, he still possesses sexual desire. It is impossible for him to find a girlfriend or a wife and, since he is aware of that, he finds Georgette, a prostitute, to make him company and to serve as a substitute for a wife he does not have. He takes her to Lavigne's restaurant on the boulevard Montparnasse where Hemingway and Hadley dined frequently in 1924-25 (Kennedy 202). After expressing initial disappointment Georgette says: “'It isn't bad here. [...] It isn't chic, but the food is all right"' (SAR 16). Taking Georgette to the restaurant reveals how lonely Jake feels due to his wound.

Although he lives in a Left Bank apartment on the boulevard St. Michel, he divides his time mostly between his office on the Right Bank, where he works as a newspaper correspondent, and Montparnasse, the "Quarter," where he hangs out mainly at a "new dive," the Cafe Select (which opened in 1925) (Kennedy 203). These two areas signify "opposing spheres of activity, the one associated with labor, responsibility, and male camaraderie, the other, leisure, excess, and sexual intrigue" (Kennedy 203). For eight chapters, Jake moves back and forth between the Right Bank and the Left; at day he sticks to his work routine, and at nigh he succumbs to his desires. The novel is charged with Jake's desire. He constantly desires Brett, yet she constantly walks off with someone else. He always returns to the Quarter to witness scenes of seduction and betrayal. There he "participates voyeuristically in the circulation of desire" (Kennedy 203). In the daytime on the Right Bank, Jake can control his feelings for 
Brett; at night, on the Left Bank, it is a different matter. Repeatedly, Jake returns to the bars and cafés of Montparnasse and becomes a regular customer at the Select:

In the cafés, he witnesses the glances, gestures, and innuendo of sexual negotiation; yet barred by his injury from bedroom sports, he affects detachment and irony. Jake's persistent return to Montparnasse betokens something more akin to self contempt, a recurrent exercise in flagellation. (Kennedy 204)

During the Paris section, Jake visits the Café Select three times. Each time he witnesses the seduction and betrayal. His first visit occurs after the taxi ride with Brett which reveals that they love each other but can never be lovers. Finding themselves sitting in the taxi "like two strangers," (SAR 350) they go to the Select. There, Brett seduces Count Mippipopolous and Jake decides to leave complaining of a "rotten headache" (SAR 378). In his apartment, he curses Brett and cries before falling asleep.

The next time when he visits the Select he observes a lovers' quarrel between Cohn and his mistress, Frances Clyne. Frances is angry because Cohn wants to break up with her. Jake does not realize that Cohn is leaving Frances for Brett, and when he and Brett are at Zelli's in Montmartre, a nightclub featuring black jazz, the drummer waves at Brett and shouts: "You can't two time-" (SAR 911) which foreshadows Brett leaving Jake for Cohn. Jake feels terrible dancing close to Brett and he has "the feeling as in a nightmare of it all being something repeated, something that [he] had been through and that now [he] must go through again" (SAR 915). He is constantly tense because of his desire for Brett yet that desire is never fulfilled and he always ends being disappointed. His desires bring him only pain and he feels as in a nightmare.

During Brett's brief absence from Paris, Jake enjoys a respite from pain in the company of his fishing buddy, Bill Gorton. Jake takes Bill to dine at Madame Lecomte's restaurant on the lle St. Louis on the Seine. They admire Notre Dame and go back through the Quarter around the Place Contrescarpe which is the same way Jake and Brett drove in a taxi. Jake, now free from sexual pressure, enjoys the landscape. However, he again goes back to the Select for "another selfpunishing encounter with Brett" (Kennedy 206). When they arrive at the café, he instantly notes her provocative appearance: "Brett [...] was sitting on a high stool, her legs crossed. She had no stockings on" (SAR 78)-her bare legs signify her sexual freedom. Brett's fiance, Mike 
Campbell, constantly repeats: "I say, Brett, you are a lovely piece"” (SAR 1104) and this reminds Jake of what he can never have. Outside the Dingo Bar on the rue Delambre Brett admits to the weekend that she has spent with Robert Cohn in San Sebastian and inflicts more pain. With this episode ends the Paris section of the book and the group leaves for Spain.

Months before The Sun Also Rises hit the bookstores in 1926, the Hemingway marriage was in shambles. The first part of Paris was definitively over. After his marriage to Pauline in May 1927, Hemingway moved into a fashionable apartment on the rue Ferou, near the place St. Sulpice. He avoided the cafés of Montparnasse and instead frequented Deux Magots and the Brasserie Lipp in St. Germain (Kennedy 208). He had been already tired of the expatriate scene. He wrote to Jane Heap in 1925 that the city was "getting all shot to hell" and seemed no longer "like the old days" (qtd. in Kennedy 209); in early 1926 he wrote from Schruns, promising to visit friends in Paris in April or May, "before the [summer] inrush of visiting Elks" (qtd. in Kennedy 209). Hemingway made little use of Paris as a fictional setting during the late 1920s. In 1933, five years after moving to Key West with his second wife, Pauline Pfeiffer, Ernest Hemingway revisited Paris. His return seemed "a big mistake" (qtd. in Kennedy 197). Some old friends had killed themselves, others clung to the past by scribbling memoirs, and everyone seemed "very discouraged" (Kennedy 197). He composed a travel letter for Esquire magazine about the "gloomy" mood of the city (Kennedy 197):

Paris is very beautiful this fall. It was a fine place to be quite young in and it is a necessary part of a man's education. We all loved it once and we lie if we say we didn't. But she is like a mistress who does not grow old and she has other lovers now.

She was old to start with but we did not know it then. We thought she was just older than we were, and that was attractive then. So when we did not love her any more we held it against her. But that was wrong because she is always the same age and she always has new lovers. (qtd. in Kennedy 197)

In this letter, he comments on his years in Paris and realizes that it is over and it can be never the same again.

Another destination mentioned in The Sun Also Rises is Spain. In the second sentence of his last book, The Dangerous Summer, Hemingway claimed to like Spain better than any country except his 
own, and privately he said he loved Spain more than any place (Josephs 221). Allen Josephs further writes:

In a section cut from the galleys of Death in the Afternoon, he explained that he had loved three peninsulas: northern Michigan, where he had spent his childhood summers hunting and fishing; Italy, where he had served as an ambulance driver in World War I; and Spain. (221)

Michigan was ruined by cutting of its forests; Italy was ruined by fascists, thus, Spain was the only good country left. He was attracted to Spain because he believed Spain's people, especially prior to the Spanish civil war, were homo naturalis-people who lived in harmony with nature (Josephs 222), and that opposition between homo naturalis and homo progressus can be seen in the Spain section of the novel.

The first important visit of Hemingway to Spain was in 1923 when he visited Spain twice to watch corridas (in May and June) and the second time in July to attend the great fiesta of San Fermin in Pamplona (Josephs 222). In 1924 Hemingway spent June and July in Spain and after the fiesta went to the mountain town of Burguete where they had fine trout fishing in the Irati River.

In July 1925 Hemingway was in Pamplona for the third time, now with a new group of friends, and this experience he would turn into the fictional basis for The Sun Also Rises. With Hemingway and Hadley at the fiesta were Donald Ogden Stewart and Bill Smith, with whom Hemingway had fished in Michigan. Lady Duff Twysden was also part of the group (Nagel 89). She was bright and beautiful, with a boy's haircut, and was going through a divorce. Her intended, Pat Guthrie, a Scotsman fond of wine, and Harold Loeb, who had been the first Jewish student at Princeton, were also there (Nagel 89). They all watched the bullfighting skill of Cayetano Ordonez (the model for Pedro Romero), who fought under the name Nino de la Palma. Lady Duff's presence created tension and caused men to fight over her, including Hemingway who exchanged blows with Loeb. Before the fiesta started he returned to Burguete to fish, only to find that lumbermen had run logs down the river, destroying the fishing.

The group of friends travels from France to Spain to attend the fiesta. When they come there, they immediately blend in. They find café Iruña which is the counterpart for café Select in Paris. The atmosphere at fiesta resembles "a wonderful nightmare" (SAR 3257); it is noisy and crowded; people are dancing on the streets; there is drinking and singing: 
The fiesta was really started. It kept up day and night for seven days. The dancing kept up, the drinking kept up, the noise went on. The things that happened could only have happened during a fiesta. Everything became quite unreal finally and it seemed as though nothing could have any consequences. It seemed out of place to think of consequences during the fiesta. All during the fiesta you had the feeling, even when it was quiet, that you had to shout any remark to make it heard. It was the same feeling about any action. It was a fiesta and it went on for seven days. (SAR 2197-2201)

Hemingway writes that "all day and all night the fiesta kept on" (SAR 2435) and "fiesta kept up without any pause" (SAR 2441) meaning they never slow down; no matter how tired they are, they do not stop partying. It is fun yet it is like a nightmare since they can never stop it. Under the influence of fiesta no one can control the passion. Fiesta and bullfighting provoke intense feelings in Jake and his friends, and beside it, there is also their own personal corrida with Brett as a matador and the rest of them as bulls. The tension is evident: Mike is blunt and constantly insults Cohn while the rest of them try to calm them down.

They all stay in the hotel of Montoya, a Spaniard who is Jake's friend. Montoya is a big fan of bullfighting just like Jake and he often hosts other aficionados-big lovers of bullfighting. Spaniards are extremely friendly and they accept the group as their own. Jake and his friends behave as they are at home and when they see painted on the banner "Hurray for Wine! Hurray for the Foreigners!," Robert Cohn asks: "Where are the foreigners?" and Bill says: "We're the foreigners'" (SAR 2192-2194). Although Spaniards are cheerful because of the arrival of foreigners, Jake's friends are not thrilled:

"Let's take the bottle and come back later," Bill said.

"I don't want to sit here on a night like this."

"Let's go and look at the English," Mike said. "I love to look at the English."

"They're awful," Bill said.

"Where did they all come from?"

"They come from Biarritz," Mike said.

"They come to see the last day of the quaint little Spanish fiesta."

"I'll festa them," Bill said. (SAR 2596-2600) 
Their contempt towards foreigners is funny because they are foreigners themselves. In the novel the people from Biarritz are always mentioned in a negative way; they are seen as the opposite of local people: they are conceited, always wearing sports clothes, and not comprehending Spanish culture. When they watch bullfighting, Hemingway describes Pedro Romero's greatness and his talent:

Romero did always, smoothly, calmly, and beautifully, what he, Belmonte, could only bring himself to do now sometimes. The crowd felt it, even the people from Biarritz, even the American ambassador saw it, finally. (SAR 3147-3149)

Pedro Romero's talent is so great that even people who do not understand bullfighting can see how magnificent Pedro Romero is. The people from Biarritz present the modern world or homo progressus versus Spaniards who represent homo naturalis.

Although Spaniards like having foreigners around-they cheer to them, drink with them, and behave friendly, they are distrustful of everything foreign. Unlike other Spaniards, Montoya trusts Jake because he sees that Jake understands bullfighting and how valuable it is in the Spanish world. However, Jake's friends are typical foreigners whose lifestyle Montoya does not approve but he accepts them because of Jake:

Montoya could forgive anything of a bull-fighter who had aficion. He could forgive attacks of nerves, panic, bad unexplainable actions, all sorts of lapses. For one who had aficion he could forgive anything. At once he forgave me all my friends. (SAR 1883-1885)

Montoya consults Jake on the matter of Pedro Romero and in that way shows his trust. Montoya and Jake are aware of Pedro Romero's value in the Spanish world and they are afraid that foreigners who do not understand Spanish values will corrupt and destroy Romero:

"Look," said Montoya. "People take a boy like that. They don't know what he's worth. They don't know what he means. Any foreigner can flatter him. They start this Grand Hotel business, and in one year they're through." [...] "He's such a fine boy," said Montoya. "He ought to stay with his own people. He shouldn't mix in that stuff." (SAR 2466-2473) 
However, Jake himself betrays Montoya and Spanish values when he introduces Brett to Pedro Romero:

Just then Montoya came into the room. He started to smile at me, then he saw Pedro Romero with a big glass of cognac in his hand, sitting laughing between me and a woman with bare shoulders, at a table full of drunks. He did not even nod. (SAR 2544-2546)

Brett is a modern woman who drinks, swears, and sleeps around and she can corrupt Pedro Romero. Montoya disapproves it just like the other local people. When Jake introduces Pedro Romero to Brett they are not happy: "He sat down and looked at her across the table. I went out. The hard-eyed people at the bull-fighter table watched me go. It was not pleasant" (SAR 2714). They believe that everything foreign is bad, including women, too.

Pedro Romero is aware of Spaniards' opinion on foreigners thus he hides that he can speak English:

"You know English well."

"Yes," he said. "Pretty well, sometimes. But I must not let anybody know. It would be very bad, a torero who speaks English."

"Why?" asked Brett.

"It would be bad. The people would not like it. Not yet." (SAR 2698-2704)

$\mathrm{He}$ is an excellent bullfighter and Spaniards appreciate his bullfighting skills. Art of toreo has a special place in Spanish culture and it is more than just a good show. As Allen Josephs, a world-renowned Hemingway scholar, says:

Many think of toreo as a sport. It is not. It may be described as a spectacle, a ritual, a ceremony, a sacrifice, or an art, but never as a sport. And as Hemingway well knew by the time he wrote the novel, toreo was often described within Spain as the tragedy of the death of the bull. (229)

Hemingway understood the Spanish sense of toreo and believed that the Spanish way of life was best exemplified in toreo.

Toreo moved Hemingway as nothing ever had. Joseph claims that Hemingway best described that experience in the passage in 
Death in the Afternoon which describes faena-the final series of passes before the kill, in which the matador uses the muleta to manoeuvre the bull into a position to stab it between the shoulders, cutting the aorta:

The faena that takes a man out of himself and makes him feel immortal while it is proceeding, that gives him an ecstasy, that is, while momentary, as profound as any religious ecstasy; moving all the people in the ring together and increasing in emotional intensity as it proceeds, carrying the bullfighter with it, he playing on the crowd through the bull and being moved as it responds in a growing ecstasy of ordered, formal, passionate, increasing disregard for death that leaves you, when it is over, and the death administered to the animal that has made it possible, as empty, as changed and as sad as any major emotion will leave you. (206-207)

Hemingway describes faena using words such as ecstasy, emotional intensity, disregard for death which leaves you empty, changed, and sad as any major emotion leaves you. Josephs explains it: "That is the Spanish context of the corrida. And that is Hemingway's context, the primordial and mythic context that stands in opposition to so much of our world" (234).

Jake understands the Spanish sense of toreo, but Brett does not. When she goes off with Pedro Romero she leaves bull's ear in the hotel drawer together with the cigarette-stubs. She does not understand Spanish values and, in the end, Pedro Romero is indeed hurt; the relationship with Brett brings him nothing good. He ends up wounded both emotionally (Brett leaves him) and physically (Cohn beats him up).

Differences between France and Spain can be seen in Brett and Pedro Romero's relationship. They are the two ends of the spectrum, just like France and Spain. Brett is a modern woman, and Pedro Romero is a traditional Spaniard. They are both beautiful and attracted to each other, yet they cannot function together because of their cultural backgrounds. Their relationship works for a while, but eventually, Pedro Romero wants to change Brett and turn her into a proper Spanish woman. Although she is beautiful he is ashamed of her which hurts Brett: "'It was rather a knock his being ashamed of me. He was ashamed of me for a while, you know'” (SAR 3522-3523). He wants her to be more traditional, to change her hair and behaviour: 
"Oh, yes. They ragged him about me at the café, I guess. He wanted me to grow my hair out. Me, with long hair. I'd look so like hell."

"It's funny."

"He said it would make me more womanly. I'd look a fright." (SAR 3524-3526)

However, Brett, with her chic hair and wardrobe, drinking, swearing, partying, and changing lovers fast, can never be a traditional woman. Although she likes Pedro Romero, she leaves him because she cannot change.

When the group leaves Spain Jake is alone in Bayonne and finally enjoys some peace and quiet. Although Jake likes it in Spain, he believes Spain is dangerous because people are not rational. In France "there was a safe, suburban feeling" (SAR 3376). Jake contemplates life in France which he finds much simpler than in Spain where people are too passionate, emotional, and have strong opinions and values:

The waiter seemed a little offended about the flowers of the Pyrenees, so I overtipped him. That made him happy. It felt comfortable to be in a country where it is so simple to make people happy. You can never tell whether a Spanish waiter will thank you. Everything is on such a clear financial basis in France. It is the simplest country to live in. No one makes things complicated by becoming your friend for any obscure reason. If you want people to like you you have only to spend a little money. I spent a little money and the waiter liked me. He appreciated my valuable qualities. He would be glad to see me back. I would dine there again some time and he would be glad to see me, and would want me at his table. It would be a sincere liking because it would have a sound basis. I was back in France. (SAR 3388)

In France he is "safe," he can easily make people like him and there are no friends like Montoya whose values he can betray. Modern, cool Paris controls and mutes their passions. In France people are rational and reserved; no one even knows about Jake's wound and his impotence. When Brett writes to Jake that she needs his help, he has to go back to Spain and considers himself a fool for going back there yet he still goes there to comfort devastated Brett: 
I hated to leave France. Life was so simple in France. I felt I was a fool to be going back into Spain. In Spain you could not tell about anything. I felt like a fool to be going back into it, but I stood in line with my passport. (SAR 3399)

Although it seems that nothing has changed, when Brett contemplates how they could have been a great couple if it were not for Jake's wound, it is implied that Jake does not believe it when he says: "Isn't it pretty to think so?'” (SAR 3611)

In the novel, Hemingway offers his view on France and Spain. Both countries have their pros and cons. While France is modern, liberal, and artistic, it has got negative sides as well - people are alienated, reserved, and dissatisfied. Spain has got a beautiful nature, friendly people, and bullfighting, however, it is too intense for Jake. Changing destination might not solve the personal problems of Jake and his friends, but at least it offered a fresh perspective; to quote Henry Miller: "One's destination is never a place, but rather a new way of looking at things" (25).

\section{References:}

Barlowe, Jamie. "Hemingway's Gender Training." A Historical Guide to Ernest Hemingway, edited by Linda Wagner-Martin, Oxford, Oxford University Press, 2000, pp. 117-155.

Hemingway, Ernest. The Sun Also Rises. Kindle ed., Scribner, 2014.

---. A Moveable Feast. New York, Charles Scribner's Sons, 1964.

---. Ernest Hemingway: Selected Letters, 1917-1961, edited by Carlos

Baker, New York, Charles Scribner's Sons, 1981.

Josephs, Allen. "Hemingway's Spanish Sensibility." The Cambridge Companion to Ernest Hemingway, edited by Scott Donaldson, New York, Cambridge University Press, 1996, pp. 221-243.

Kennedy, J. Gerald. "Hemingway, Hadley, and Paris: The persistence of desire." The Cambridge Companion to Hemingway, edited by Scott Donaldson, New York, Cambridge University Press, 1996, pp. 197-221.

Martin, Wendy. "Brett Ashley as New Woman in The Sun Also Rises." New Essays on The Sun Also Rises, edited by Linda WagnerMartin, New York, Cambridge University Press, 1987, pp. 65-83.

Miller, Henry. Big Sur and the Oranges of Hieronymus Bosch. New York, New Directions Publishing, 1957. 
Nagel, James. "Brett and the other women in The Sun Also Rises." The Cambridge Companion to Ernest Hemingway, edited by Scott Donaldson, New York, Cambridge University Press, 1996, pp. 87-109.

\section{PARIZ I ŠPANIJA U ROMANU SUNCE SE PONOVO RAEA ERNESTA HEMINGVEJA}

Ernest Hemingway potječe iz Oak Parka u Illinoisu, međutim više je pisao o drugim mjestima nego o svome rodnome mjestu. Pariz i Španjolska mjesto su radnje njegovoga prvog romana Sunce se ponovno rađa. U Hemingwayevom romanu grupa prijatelja besciljno luta od mjesta do mjesta pokazujući da su uistinu izgubljena generacija koja živi život bez ikakvoga cilja i plana. Ovaj rad pokazat će kako promjena destinacije utječe na grupu prijatelja: moderni, hladni Pariz utišava i kontrolira njihove strasti, dok španjolska fiesta čini da one podivljaju. U Hemingwayevom romanu Pariz i Španjolska potpune su suprotnosti. Pariz i Španjolska često se doživljavaju kao romantična mjesta, međutim Hemingway će pokazati i njihove negativne strane kao što su amoralnost Pariza te konzervativnost Španjolske. U boemskome Parizu moguće je vidjeti sve - od homoseksualaca do prostitutki, dok tradicionalna Španjolska gleda sa zgražanjem i čuđenjem čak i na Brett i njen stil oblačenja i frizuru.

Ključne riječi: Pariz, Španjolska, destinacija, izgubljena generacija, borba bikovima, fiesta. 